\title{
Estradiol reduces connexin 43 gap junctions in the uterus during adenomyosis in cows
}

\author{
A.J. Korzekwa, M. Łupicka, B.M. Socha, A.A. Szczepańska \\ Department of Reproductive Immunology and Pathology, \\ Institute of Animal Reproduction and Food Research, \\ Polish Academy of Sciences, 10-748 Olsztyn, Poland
}

\begin{abstract}
Adenomyosis is defined as the presence of glandular foci external to the endometrium of the uterus, either in the myometrium or/and perimetrium, depending on the progress of this dysfunction. To date, we showed that steroids secretion and prolactin expression and proliferative processes are disturbed during uterine adenomyosis in cows. During endometriosis in eutopic endometrium in women, gap junctions are down regulated. The transmembrane gap junction protein, connexin (Cx43) is necessary for endometrial morphological, biochemical and angiogenic functions. The aim of this study is recognition of adenomyosis etiology by determination of the role of Cx43 in this process. Immunolocalization and comparison of $\mathrm{Cx} 43 \mathrm{mRNA}$ and protein expression in healthy $(\mathrm{N}=9)$ and adenomyotic uterine tissue ( $\mathrm{N}=9$ ), and $\mathrm{Cx} 43$ mRNA expression (real time $\mathrm{PCR}$ ) in uterine stromal - myometrium co-culture under 24-hour stimulation with 17 -beta estradiol $\left(10^{-7} \mathrm{M}\right)$ isolated from healthy $(\mathrm{N}=5)$ and adenomyotic $(\mathrm{N}=5)$ cows were determined.

$\mathrm{Cx} 43$ was localized in healthy and adenomyotic uteri. mRNA and protein expression was down-regulated in uterine tissue in adenomyotic compared with healthy cows $(p<0.05)$. Estradiol stimulated Cx43 mRNA expression in myometrial cell culture and co-culture of stromal and myometrial cells in adenomyotic compared with healthy cows $(\mathrm{p}<0.05)$. In summary, down-regulation of $\mathrm{Cx} 43$ expression in the junction zone might play an important role in pathogenesis of adenomyosis. Estradiol modulates gap junctions during adenomyosis.
\end{abstract}

Key words: uterus, gap junction, connexin, adenomyosis, cow

\section{Introduction}

Adenomyosis is a uterine dysfunction characterized by the presence of endometrial glands with stromal elements in the myometrium (Azziz 1989, Campo et al. 2012) but the etiology of this disorder is still unclear (Ferenczy 1998, Korzekwa et al. 2014). Our previous studies showed that in cows the fre- quency and progression of adenomyosis are positively correlated with age, what is consistent with studies on women. The cows older than 5 years had advanced stages of adenomyosis (approx. $40 \%$ of animals; Korzekwa et al. 2013). Moreover, the presence of adenomyosis did not differed based on the sampling location in the uterus. The glandular nests in adenomyotic cows were present in myometrial layer of both uterine

Correspondence to: A. Korzekwa, e-mail: a.korzekwa@pan.olsztyn.pl, tel.: 48895393130 
horns, ipsilateral and contralateral to ovary with corpus luteum (CL), and near the cervix as well (Korzekwa et al. 2013, Lupicka et al. 2015).

Gap junctions are intercellular channels that permit communication between cells by cytoplasmic exchange of small molecules including metabolites and second messengers, as well as ions that transmit electrical impulses between neighboring cells (Evans and Martin 2002). A gap junction channel is composed of two hemi-channels (connexons), each of which is composed of six protein subunits (connexins -Cxs) arranged around a pore. Connexin43 $\left(\mathrm{C}_{x} 43\right)$ and $\mathrm{Cx} 32$ are the two most abundant Cxs and are expressed in numerous tissues including the ovary, placenta and decidua in several species, including cattle (Wiesen and Midgley 1993, 1994, Mayerhofer and Garfield 1995, Wrenzycki et al. 1995, van Engelen et al. 2009, Xu et al. 2015).

In addition, a channel-independent role of Cxs in intracellular signaling by interacting with other proteins has been suggested (Saez et al. 2003). Expression of the different Cxs must be properly controlled as their misregulation may contribute to diseases. As a consequence, mutations in $\mathrm{Cx}$ proteins resulting in modulation of channel properties are associated with a large variety of specific pathologies (Araya et al. 2005).

During adenomyosis in cows, protein expression of the 17-beta estradiol (E2) receptor $\alpha(\mathrm{ER} \alpha)$ is increased and blood and endometrial E2 concentrations are elevated, indicating hormonal abnormalities during this condition (Campo et al. 2012). Invasion by adenomyotic stromal cells was higher after E2 treatment in an in vitro model of stromal and myometrial co-culture of human cells (Taylor et al. 2014). Estradiol increases Cx43 mRNA expression in rat endometrium (Grümmer et al. 1994) but also in the myocardium (Chen et al. 2010). Moreover, E2 stimulated Cx43 mRNA expression in human myometrial uterine cells ( $\mathrm{Di}$ et al. 2001). The existence of estrogen response elements within the $\mathrm{Cx} 43$ gene and evidence implicating E2 in the induction of Cx43 transcription has been reported (Petrocelli and Lye 1993, Lye et al. 1993) providing a molecular basis for the reported estrogenic stimulation of $\mathrm{Cx} 43$ synthesis (Chung et al. 2004). Therefore, we designed an in vitro model using co-culture of stromal and myometrial uterine cells isolated from healthy and adenomyotic cows for comparing E2 effect on Cx43 mRNA expression.

The aims of the study were: (1) Cx43 immunolocalization and comparison of Cx43 mRNA and protein expression in healthy and adenomyotic uterine tissues, (2) determination of Cx43 mRNA expression in co-cultured uterine stromal and myometrial cells isolated from healthy and adenomyotic cows under stimulation with E2.

\section{Materials and Methods}

\section{Material collection}

All procedures were approved by the Local Animal Care and Use Committee, Olsztyn, Poland (agreement no. 83/2012/N).

From a total of 30 examined cows, 18 Holstein/Polish Black and White cows $(75 \% / 25 \%$, respectively), 5-7 years old, were used in the experiments for post mortem collection of uteri (days 8-10 of the oestrous cycle). These days of the estrous cycle were selected for experiments because this study is continuation of our concerning adenomyosis (Korzekwa et al. 2013, 2014, Łupicka et al. 2015) and adenomyosis has been observed during the luteal stage of the estrous cycle in cattle (Moreira et al. 2007). Uterine tissues were obtained at the Meat Processing Plant „Warmia” (Biskupiec, Poland) and transported on ice to the laboratory within $40 \mathrm{~min}$. Day of the oestrous cycle was evaluated by macroscopic observation of the ovaries and uterus (Miyamoto et al. 2000) and confirmed by determination of progesterone (P4) levels in peripheral blood plasma collected from the jugular vein using radioimmunoassay (RIA). The level of P4 ranged from 15 to $20 \mathrm{ng} / \mathrm{ml}$. Just before slaughter, each animal was examined by a veterinarian via per rectum ultrasound-guided examination to exclude abnormal ovary structure. The reasons for culling animals from the herd were of economic nature and herd renewal, none of used for experiments cows was earlier treated for endometritis.

Tissue fragments (cross-sections of the uterine wall, i.e., endometrium and myometrium) were obtained from the middle segment of the uterine horn ipsilateral to the corpus luteum and were divided into three pieces: the first one was fixed in $4 \%$ paraformaldehyde (PFA) in 0.1 M PBS (pH 7.4) for histo- and immunohistofluorescence staining, the second was frozen and stored at $-86^{\circ} \mathrm{C}$ for further mRNA and protein expression determination in uterine tissue (endometrium with myometrium), and the third piece was used for immediate isolation and culture of uterine cells.

The tissues for experiments were divided into normal (uteri without endometrial glands within the myometrial layer, $n=9$ ) and adenomyotic (endometrial foci present in the myometrium, $n=9$ ), based on microscopic observation of hematoxylin and eosin-stained uterine cross-section slices. 


\section{Uterine cell isolation and in vitro culture}

Endometrial stromal cells were isolated by enzymatic dissociation as previously described (Łupicka et al. 2015). After endometrial cell isolation, the myometrial layer of the uterus was dissected with scissors. About $4 \mathrm{~cm}$-long fragments of muscle tissue were chopped up with scissors into a homogeneous material. Approximately $5 \mathrm{~g}$ of the chopped tissue was digested in $50 \mathrm{ml}$ of M199 medium (Sigma, M2520, St. Louis, MO, USA) containing $0.1 \%$ of bovine serum albumin (BSA; Sigma, A2058), 20 $\mu \mathrm{g} / \mathrm{ml}$ of gentamicin (Sigma, G1271), $2 \mathrm{mg} / \mathrm{ml}$ of collagenase I (Sigma, C0130), $1 \mathrm{mg} / \mathrm{ml}$ of deoxyribonuclease (Sigma, D5025) and $2 \mathrm{mg} / \mathrm{ml}$ of dispase (Life Technologies, 17105-041, Paisley, UK). The enzyme solution with myometrial tissue was held at $37.5^{\circ} \mathrm{C}$ with stirring for $30 \mathrm{~min}$. After digestion, the cell suspension was filtered through a mesh to remove undigested tissue fragments, then the cells were washed by centrifugation $\left(10 \mathrm{~min}\right.$ at $100 \mathrm{x} \mathrm{g}$, at $\left.4^{\circ} \mathrm{C}\right)$. Cells were resuspended in culture medium (DMEM; Sigma, D5796) supplemented with $10 \%$ of fetal calf serum (FCS; Sigma, 12133C) and antibiotics (gentamicin/amphotericin B; Life Technologies, 1153727).

Uterine cells were plated in a co-culture system, in which myometrial cells were cultured at the bottom of wells in 6-well culture plates (basal compartment) and stromal cells were cultured on collagen-coated inserts (Biocoat ${ }^{\circledR}$ Cell Culture Inserts Collagen Type I, BD Biosciences, Bedford, MA; apical compartment) at $37.5^{\circ} \mathrm{C}$ in a humidified atmosphere of $5 \% \mathrm{CO}_{2}, 95 \%$ air. Both cell types were cultured in a phenol red-free DMEM medium containing $10 \%$ of fetal calf serum (FCS; Sigma, 12133C) and antibiotics. The medium (DMEM with $10 \%$ FCS and antibiotics) was changed every 2 days until $70 \%$ confluence was reached (approx. on the $4^{\text {th }}$ day of culture). For the last $24 \mathrm{~h}$ of culture, inserts with stromal cells were replaced with myometrial cells. After changing the medium for DMEM containing $0.1 \%$ BSA and antibiotics, the co-cultures were stimulated with E2 $\left(10^{-7} \mathrm{M}\right)$. Total mRNA and cell lysates were collected from the cultures. Cell culture homogeneity was confirmed using real-time PCR for determination of mRNA expression of vimentin and desmin for stromal and myometrial cells, respectively, in separate cultures, before establishing co-cultures (Zeiler et al. 2007).

\section{Experimental procedures}

\section{Experiment 1. Localization, mRNA and protein expression of connexin 43 in uterine tissues of healthy and adenomyotic cows}

Cx43 immunolocalization (immunofluorescence) and comparison of Cx43 mRNA (real time PCR) and protein (Western blotting) expression in healthy $(\mathrm{N}=9)$ and adenomyotic uterine tissue $(\mathrm{N}=9)$ was proceeded.

\section{Experiment 2. The effect of 17-beta estradiol on Cx43 mRNA expression in uterine stroma - myometrium co-culture of healthy and adenomyotic cows}

Cx43 mRNA expression (real time PCR) was evaluated in uterine stromal, myometrial cells and in myometrial cells co-cultured with stromal cells after $24 \mathrm{~h}$ stimulation with $\mathrm{E} 2$ in healthy $(\mathrm{N}=5)$ and adenomyotic $(\mathrm{N}=5)$ cows.

The stroma - myometrium co-cultures, after receiving the $70 \%$ of confluence, were stimulated for $24 \mathrm{~h}$ with E2 $\left(10^{-7} \mathrm{M}\right)$. Cells were isolated from healthy $(\mathrm{N}=5)$ and adenomyotic $(\mathrm{N}=5)$ cows. The effective dose of $\mathrm{E} 2$ was selected based on the preliminary study.

\section{Histochemical staining}

Uterine tissue was fixed in 4\% PFA and processed for a standard haematoxylin and eosin staining protocol. Stained cross-sections of the tissue were observed under a light microscope (Nikon FXA, Tokyo, Japan). Animals were classified as described previously (Korzekwa et al. 2013, Lupicka et al. 2015); briefly, if uterine glands were present only in the endometrium, and if the endometrial-myometrial border was clearly visible, cows were classified as normal/control. Whereas, if the glands penetrated the myometrial layer of the uterus, animals were classified as adenomyotic (according to the classification of Katkiewicz et al. 2005, data not shown).

\section{Immunofluorescence staining}

Immunohistofluorescence was used to localise $\mathrm{C} \times 43$ in uterine tissues. Cross-sections of uterine horn samples were fixed in 4\% PFA in $0.1 \mathrm{M}$ PBS $(\mathrm{pH} 7.4)$, and cryoprotected in $18 \%$ sucrose. Immunostaining was carried out on consecutive $7 \mu \mathrm{m}$ 
Table 1. Oligonucleotide sequences used for real-time PCR.

\begin{tabular}{clcc}
\hline Gene & \multicolumn{1}{c}{ Oligonucleotide sequences } & Product size (bp) & GeneBank \\
\hline \multirow{2}{*}{ vimentin } & FWD 5'-GACCTGGAGCGTAAAGTGG-3' & 108 & BC118269 \\
& REV 5'-GACATGCTGTTCTTGAATCTGG-3' & & BC133410 \\
\hline \multirow{2}{*}{ desmin } & FWD 5'-GACCCAGGCAGCCAACAAG-3' & 100 & J05535 \\
& REV 5'-GTCGATCTCGCAGGTGTAGG-3' & 125 & BC102589 \\
\hline \multirow{2}{*}{$c x 43$} & FWD 5'-TGAGTGCCGTTTACACTTGC-3' & 103 & \\
& REV 5'-GGCAAGAGACACCAATGACA-3' & & \\
\hline \multirow{2}{*}{ GAPDH } & FWD 5'-CACCCTCAAGATTGTCAGCA-3' & & \\
& REV 5'-GGTCATAAGTCCCTCCACGA-3' & & \\
\hline
\end{tabular}

cryostat sections. To block endogenous peroxidase, the sections were treated with hydrogen peroxide in methanol and washed in 0.1 M PBS. The sections were blocked with $10 \%$ normal donkey serum (Sigma, G9023) for $1 \mathrm{~h}$ at room temperature (approx. $23^{\circ} \mathrm{C}$; RT), and incubated overnight at RT with a 1:500 dilution of anti-Cx43 (Sigma, C8093), Next, the cells were washed $3 \mathrm{x}$ with $\mathrm{PBS}$ and incubated $1 \mathrm{~h}$ at RT with secondary antibodies conjugated with cyanine 3 ( $\mathrm{CY}^{3}$; Jackson ImmunoResearch, West Grove, PA, 715-165-150). Connexin43 was visualized with confocal imaging using a Nikon $\mathrm{C} 1$ confocal microscope.

\section{Total RNA isolation}

Total RNA was extracted from uterine tissues (approx. $30 \mathrm{mg}$ ) and from cultured cells using TRI-Reagent (Sigma, T9424) according to the manufacturer's instructions. The content and purity of RNA was assessed on a NanoDrop 1000 (Thermo Fisher Scientific, ND-1000, Wilmington, DE, USA). One microgram of each sample of total RNA was reverse-transcribed to cDNA with the QuantiTect Reverse Transcription kit (Life Technologies, 205313), as described in the supplier's protocol. The cDNA obtained was stored at $-20^{\circ} \mathrm{C}$ until real-time PCR was applied.

\section{Real-time PCR quantification}

mRNA expression for $C x 43$ in tissues and cells was determined by quantitative real-time PCR. The experiments were performed using the Applied Biosystems 7900 (Applied Biosystems, Foster City, CA, USA) with SensiFAST SYBR Hi-ROX Kit (Bioline Reagents, BIO-92002, London, UK) according to the manufacturer's instructions. The real-time PCR reaction mix $(20 \mu \mathrm{l})$ contained $19 \mu \mathrm{l}$ of SensiFAST SYBR Hi-ROX Master Mix, $0.5 \mu \mathrm{M}$ of sense and antisense primers, and $1 \mu \mathrm{l}$ of reverse-transcribed
cDNA (50 ng). Primer sequences used for determination of $C x 43$ and glyceraldehyde 3-phosphate dehydrogenase $(G A P D H)$ mRNA expression are detailed in Table 1. Standard curves consisting of serial dilutions of the appropriate cDNA were plotted for efficiency evaluation. Amplification was initiated by an initial enzyme activation step $\left(2 \mathrm{~min}, 95^{\circ} \mathrm{C}\right)$. The PCR steps were as follows: 40 cycles of denaturation $\left(5 \mathrm{sec}, 95^{\circ} \mathrm{C}\right)$, then annealing and extending (20 sec, $\left.60^{\circ} \mathrm{C}\right)$. After amplification, melting curves were acquired by stepwise increases of temperature from 50 to $95^{\circ} \mathrm{C}$ to ensure that a single product was amplified and no primer-dimer structures were formed. Control reactions in the absence of the template or primers were performed to confirm that products were free from genomic DNA contamination. Dissociation curves analysis was carried out after each realtime experiment to confirm the presence of only one amplification product. Data were normalized using the $\Delta \Delta \mathrm{C}_{\mathrm{t}}$ method. Samples were amplified in duplicates. Data are shown as the average fold increase, with S.E.M., and are expressed relative to the housekeeping gene $G A P D H$.

\section{Western blotting}

Protein expression for $\mathrm{Cx} 43$ in the tissues and cells was determined by Western blotting. Proteins from homogenized tissues and in vitro cultured cells were released with lysis buffer containing $50 \mathrm{mM}$ Tris- $\mathrm{HCl}$ ( $\mathrm{pH} 8.0), 150 \mathrm{mM} \mathrm{NaCl}, 5 \mathrm{mM}$ EDTA, $0.1 \%$ SDS, $1 \%$ TritonX-100, $0.5 \%$ sodium deoxycholate and protease inhibitors (Sigma, P8340). The lysates were stored at $-86^{\circ} \mathrm{C}$ until further analysis. Protein concentrations were measured by the Bradford's method.

Western blot analysis was performed as previously described (Korzekwa et al. 2011). Equal amounts of protein were dissolved in SDS gel-loading buffer, heated to $95^{\circ} \mathrm{C}$ for $4 \mathrm{~min}$ and separated in $10 \%$ SDS-PAGE gel. Separated proteins were electrob- 

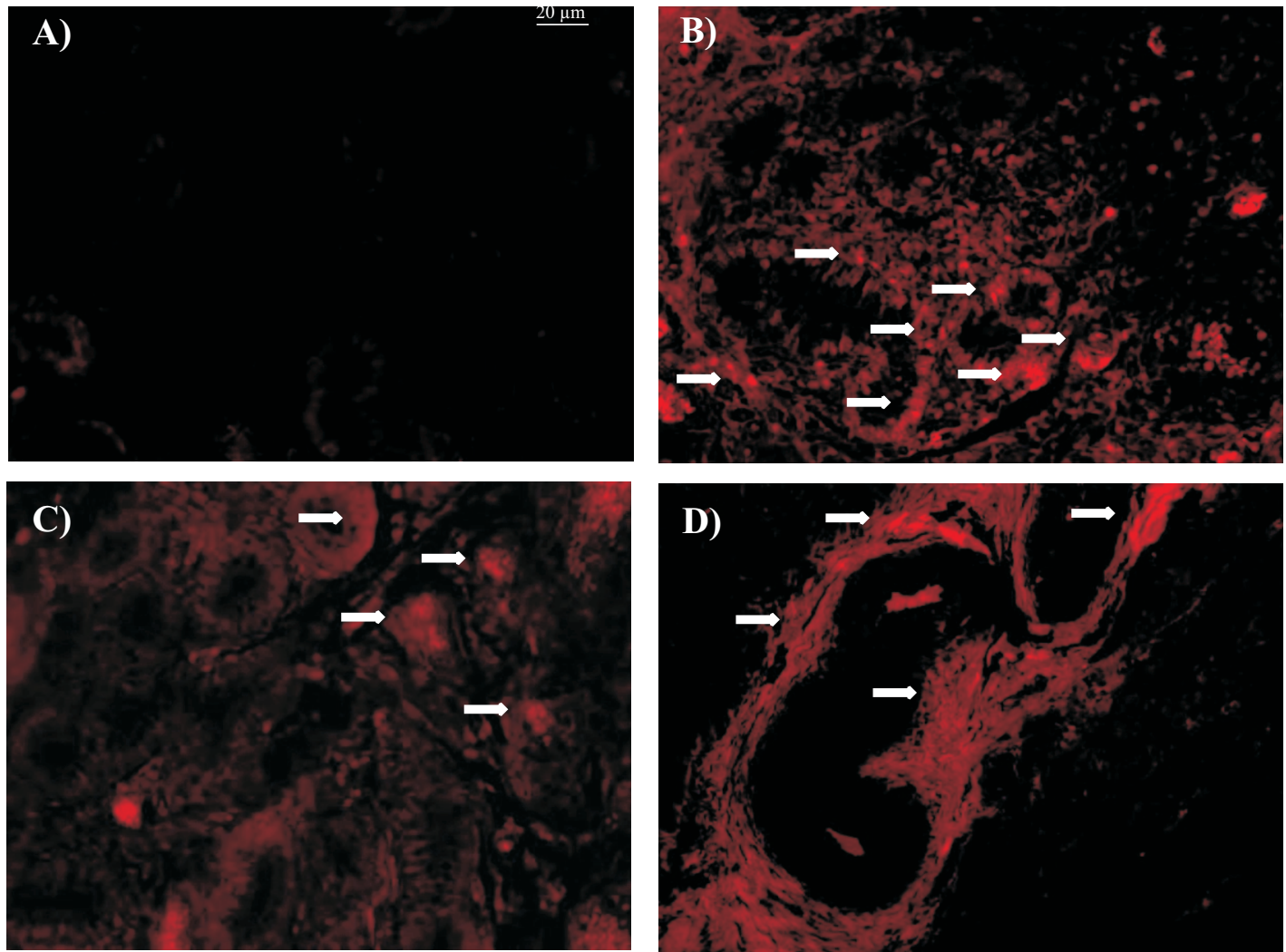

Fig. 1. Immunfluorescence detection of $\mathrm{Cx} 43$ in uterine tissues from control cows and from cows with adenomyosis. A - negative control, B - Cx43 in adenomyotic tissue, $\mathrm{C}-$ in healthy tissue. Arrows indicate the most intense histochemical reactions. Scale bars: $20 \mu \mathrm{m}$.

lotted onto $0.2 \mu \mathrm{m}$ nitrocellulose membranes in transfer buffer. After blocking in 5\% non-fat dry milk in TBS-T buffer for $1.5 \mathrm{~h}$ at RT, the membranes were incubated overnight with a 1:500 dilution of anti-Cx43 (Sigma, C8093) antibodies; GAPDH (Sigma, G8795; monoclonal anti-glyceraldehyde-3-phosphate dehydrogenase antibody produced in mouse) expression was used as a reference. Proteins were detected by incubating the membranes with a 1:20,000 dilution of secondary polyclonal anti-mouse alkaline phosphatase-conjugated antibody (Sigma, A 3562) for $1.5 \mathrm{~h}$ at RT. Western blots were quantitated using the Kodak 1 D program (Eastman Kodak, Rochester, NY, USA).

\section{Hormone determination}

Measurements of P4 in blood plasma were performed using a direct radioimmunoassay (RIA; DIASource ImmunoAssays S.A., Nivelles, Belgium). The standard curve ranged from 0.12 to $36 \mathrm{ng} / \mathrm{ml}$ and the effective dose for $50 \%$ inhibition (ED 50) of the assay was $0.05 \mathrm{ng} / \mathrm{ml}$. The intra- and inter-assay coefficients of variation (CV) were $6.5 \%$ and $8.6 \%$, respectively.

\section{Statistical analysis}

In Experiment 1, statistically significant differences in mRNA and protein expression between healthy and adenomyotic uterine tissue were detected using Student's $t$-test (GraphPad PRISM Version 5.00, San Diego, CA, USA). The data are shown as the mean \pm SEM of values obtained in nine separate experiments. The results were considered significantly different when $\mathrm{p}<0.05$.

In Experiment 2, statistically significant differences in mRNA expression between healthy and adenomyotic uterine cells and between control and E2 stimulated cells were performed using two-way ANOVA followed by the Bonferroni multiple comparison test (GraphPad). All data were expressed as means \pm SEM. Differences were considered significant at $\mathrm{p}<0.05$.

\section{Results}

\section{Preliminary division of the material}

Based on microscopic examination of hematoxylin and eosin stained tissue slices, bovine uteri were divided into two groups: control and adenomyotic. 
a)
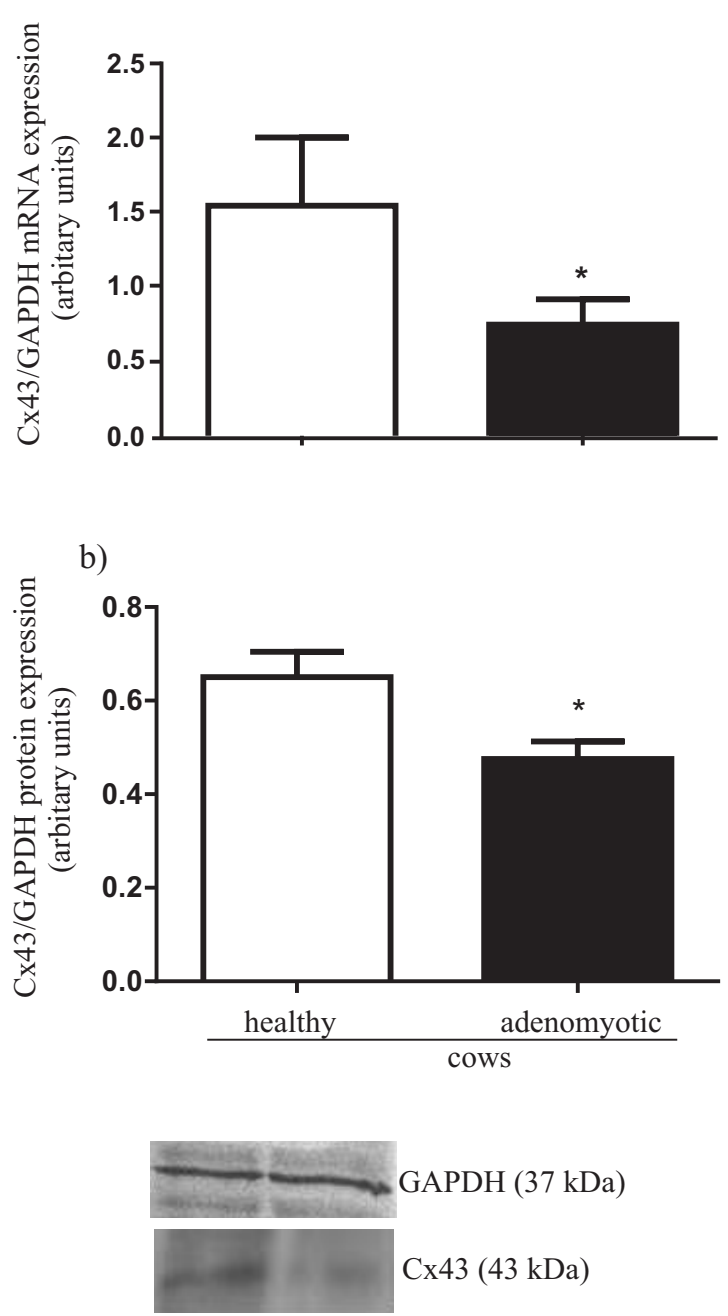

Fig. 2. mRNA (a) and protein (b) expression of $\mathrm{Cx} 43$ in uterine tissues obtained from control cows and from cows with adenomyosis. Data were normalized against glyceraldehyde-3-phosphate dehydrogenase $(G A P D H)$. Bars represent the mean \pm SEM. Asterisks indicate statistical difference between uterine normal and adenomyotic tissues $(\mathrm{p}<0.05)$, as determined by Student's $t$-test. Representative blots for $\mathrm{Cx} 43$ and GAPDH are shown below the graphs.

\section{Experiment 1. Localization, mRNA and protein expression of connexin 43 in uterine tissues of healthy and adenomyotic cows}

Immunofluorescence revealed the localization of Cx43 in uteri of healthy and adenomyotic cows. The protein was localized in the endometrium as well in the myometrium layer of uteri. Figure 1A represents control tissue with $\mathrm{Cx} 43$ antibody omitted. In the case of adenomyotic tissues, immunoreactivity was observed near the glands located in endometrium and myometrium, characteristic for adenomyosis a) STROMAL CELLS
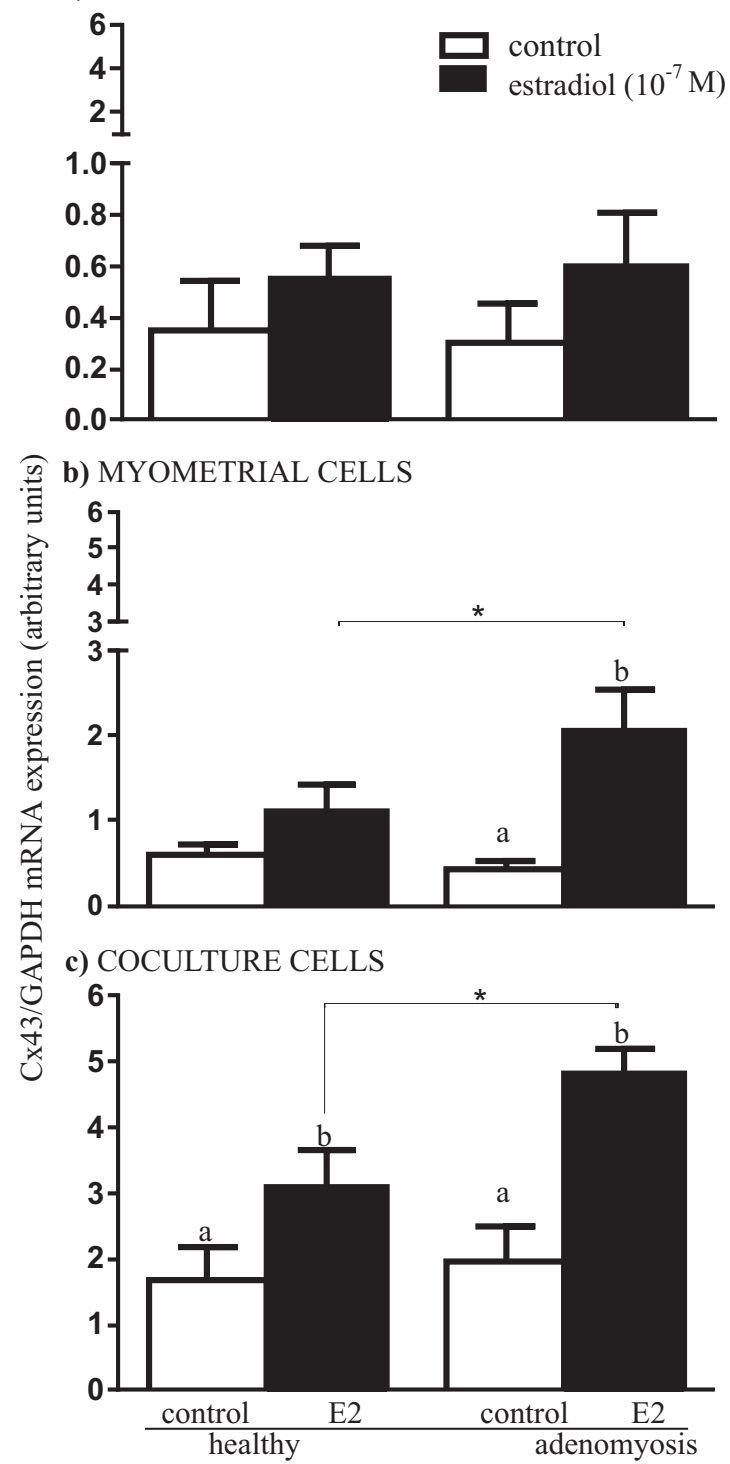

Fig. 3. mRNA expression of Cx43 in stromal (a), myometrial (b) and co-cultured, stromal and myometrial (c) uterine cells isolated from control cows and from cows with adenomyosis. Data were normalized against glyceraldehyde-3-phosphate dehydrogenase $(G A P D H)$. Statistical differences were analysed by two-way ANOVA followed by the Bonferroni multiple comparison test (GraphPad). All data were expressed as means \pm SEM. Differences were considered significant at $\mathrm{p}<0.05$. Asterisks indicate statistical differences between uterine normal and adenomyotic groups and different letters $(\mathrm{a}, \mathrm{b})$ between control and E2 treatment $\left({ }^{*} \mathrm{p}<0.05\right)$.

(Fig. 1B). In healthy cows $\mathrm{Cx} 43$ immunoreactivity was observed in endometrium, and near blood vessels in myometrium (Fig. 1C,D).

mRNA and protein expression of Cx43 was decreased in adenomyotic uterine tissue compared with normal uteri ( $\mathrm{p}<0.05$, Fig. $2 \mathrm{~A}, \mathrm{~B})$. 


\section{Experiment 2. The effect of 17-beta estradiol on Cx43 mRNA expression in uterine stroma - myometrium co-culture of healthy and adenomyotic cows}

The expression of $\mathrm{Cx} 43$ was not different between healthy and adenomyotic cows and E2 did not influence $\mathrm{Cx} 43$ expression in stromal cells ( $p>0.05$; Fig. 3A).

In myometrial cells, expression of $\mathrm{Cx} 43$ increased after E2 stimulation in the adenomyotic group and the effect of E2 was higher in adenomyotic myometrial cells compared with healthy cells $(\mathrm{p}<0.05$; Fig. 3B).

In co-culture of stromal and myometrial cells, mRNA expression of Cx43 was elevated after E2 stimulation $(\mathrm{p}<0.05)$. Moreover the increase in expression after E2 treatment was higher in adenomyotic compared with healthy cell co-cultures $(\mathrm{p}<0.05$; Fig. 3C).

\section{Discussion}

The present study demonstrated, for the first time, Cx43 mRNA and protein expression and localization in uterine tissue and cells during the estrous cycle in cows. mRNA and protein expression of $\mathrm{Cx} 43$ was decreased in adenomyotic uterine tissue compared with normal uteri. Moreover differences in Cx43 expression during adenomyosis including the effect of E2 were examined. In uterine stroma - myometrium co-culture of adenomyotic cows, E2 caused increase of Cx43 mRNA expression with healthy cell co-cultures.

So far, $\mathrm{Cx} 43$ function have been described in connection with pregnancy and labor in human (Laws et al. 2008), porcine (Romek and Karasiński 2011) and mouse (Doring et al. 2006) uteri. All these studies reported an increase in $\mathrm{Cx} 43$ in the myometrium during term and preterm delivery as essential for the development of uterine contractions. Xu et al. (2015) have showed lately that in human uterine myometrial cells prostaglandin F2alpha directly stimulated $\mathrm{Cx} 43$ protein expression. Thus, prostaglandins as main factors influencing on uterine function regulate $\mathrm{Cx} 43$ and this regulation may also differ during adenomyosis but it demands further study.

During pathological conditions, gap junctions in the uterus are supposed to be dysregulated. Connexin43 immunohistostaining and protein expression were inhibited in uterus with diagnosed endometriosis comparing with uteri of healthy women (Yu et al. 2014). In our study, we demonstrated decreased $\mathrm{Cx} 43$ mRNA and protein expression in adenomyotic uteri, which is in accordance with the results concerning
Cx43 expression during endometriosis in women. Nevertheless, in our in vitro experiment, $\mathrm{Cx} 43 \mathrm{mRNA}$ expression was similar in stromal, myometrial and co-cultured cells of healthy and adenomyotic cows. The discrepancies between results obtained from uterine tissue and cells may arise because Cx expression is regulated by other factors that are not present during culture of pure cells.

The pathogenesis and aetiology of both endometriosis and adenomyosis are still unclear but during both disorders E2 overproduction has been observed (Takahashi et al. 1989, Chen et al. 2010, Korzekwa et al. 2013). In our study, E2 stimulated $\mathrm{Cx} 43$ mRNA expression in myometrial and co-cultured both myometrial and stromal cells collected from adenomyotic cows as well as in co-cultures of cells derived from healthy animals.

Estradiol is necessary to provoke $\mathrm{Cx} 43$ expression if the putative estrogen response elements are located in the Cx43 gene region (Lefebvre et al. 1995). The connection between $\mathrm{Cx} 43$ and endometriosis of uterus were described by Regidor et al. (1997). These authors observed $\mathrm{Cx} 43$ by immunohistostaining, which was correlated with a high E2 serum level in women. Our results indicate that during adenomyosis, especially in myometrial cells, E2 which is a potential inducer of this disease increases gap junction formation in the bovine uterus, which may support the migration of glands from the stroma to the myometrium.

In conclusion, our results revealed that during adenomyosis in the bovine uterus, gap junctions are expressed at a lower level than in healthy cows in the mid-luteal stage. Moreover, Cx43 expression is stimulated by E2 in adenomyotic myometrial and co-cultured stromal and myometrial uterine cells. These data suggest the involvement of gap junctions in development of adenomyosis and a correlation between E2 influence and gap junction increase. However, elucidating the connections between steroids and gap junctions and the molecular mechanism of E2 action during adenomyosis of the uterus in cattle will require further study.

\section{Acknowledgements}

The authors wish to thank W. Krzywiec for technical support and tissue collection and M. Domin - the owner of the slaughterhouse (Meat Processing Plant „Warmia”, Biskupiec, Poland) for permitting collection of the material. We are grateful to dr. G. Bodek (Laboratory in vitro, Institute of Animal Reproduction and Food Research of PAS, Olsztyn, Poland) for making pictures of uterine $\mathrm{Cx} 43$ histostaining observed under fluorescence confocal microscope. 


\section{References}

Araya R, Eckardt D, Maxeiner S, Krüger O, Theis M, Willecke K, Sáez JC (2005) Expression of connexins during differentiation and regeneration of skeletal muscle: functional relevance of connexin43. J Cell Sci 118: 27-37.

Azziz R (1989) Adenomyosis: current perspectives. Obstet Gynecol Clin North Am 16: 221-235.

Campo S, Campo V, Benagiano G (2012) Infertility and adenomyosis. Obstet Gynecol Int 2012: 786132.

Chen CC, Lien HY, Hsu YJ, Lin CC, Shih CM, Lee TM (2010) Effect of pravastatin on ventricular arrhythmias in infarcted rats: role of connexin43. J Appl Physiol 109: 541-552.

Chen YJ, Li HY, Hunag CH, Twu NF, Yen MS, Wang PH, Chou TY, Liu YN, Chao KC, Yang MH (2010) Oestrogen-induced epithelial-mesenchymal transition of endometrial epithelial cells contributes to the development of adenomyosis. J Pathol 222: 261-270.

Chung TH, Wang SM, Wu JC (2004) 17beta-estradiol reduces the effect of metabolic inhibition on gap junction intercellular communication in rat cardiomyocytes via the estrogen receptor. J Mol Cell Cardiol 37: 1013-1022.

Di WL, Lachelin GC, McGarrigle HH, Thomas NS, Becker DL (2001) Oestriol and oestradiol increase cell to cell communication and connexin 43 protein expression in human myometrium. Mol Hum Reprod 7: 671-679.

Doring B, Shynlova O, Tsui P, Eckardt D, Janssen-Bienhold U, Hofmann F, Feil S, Feil R, Lye SJ, Willecke K (2006) Ablation of connexin 43 in uterine smooth muscle cells of the mouse causes delayed parturition. J Cell Sci 119: $1715-1722$.

Evans WH, Martin PE. Gap junctions: structure and function (review) (2002) Mol. Membr. Biol 19: 121-136.

Ferenczy A (1998) Pathophysiology of adenomyosis. Hum Reprod 4: 312-322.

Grummer R, Chwalisz K, Mulholland J, Traub O, Winterhager E (1994) Regulation of connexin26 and connexin43 expression in rat endometrium by ovarian steroid hormones. Biol Reprod 51: 1109-1116.

Katkiewicz M, Wierzchoń M, Boryczko Z (2005) Adenomyosis of cows; uterus - latent cause of infertility? Med Wet 61: 1378-1381.

Korzekwa AJ, Bah MM, Gęstwicka M, Socha B, Skarżyński DJ (2013) Adenomyosis in the bovine uterus: correlation between frequency, age, and 17 $\beta$-estradiol - progesterone equilibrium. Theriogenology 79: 165-172.

Korzekwa AJ, Bodek G, Bukowska J, Blitek A, Skarzynski DJ (2011) Characterization of bovine immortalized luteal endothelial cells: action of cytokines on production and content of arachidonic acid metabolites. Reprod Biol Endocrinol 9: 1-9.

Korzekwa A, Łupicka M, Socha B, Mannelli Ch, Skarzynski DJ (2014) Is adenomyosis a problem in reproduction and fertility? Pol J Vet Sci 17: 187-194.

Laws MJ, Taylor RN, Sidell N, DeMayo FJ, Lydon JP, Gutstein DE, Bagchi MK, Bagchi IC (2008) Gap junction communication between uterine stromal cells plays a critical role in pregnancy-associated neovascularization and embryo survival. Development 135: 2659-2668.

Lefebvre DL, Piersanti M, Bai XH, Chen ZQ, Lye SJ (1995)
Myometrial transcriptional regulation of the gap junction gene, connexin-43. Reprod Fertil Dev 7: 603-611.

Łupicka M, Socha B, Szczepańska A, Korzekwa A (2015) Expression of pluripotency markers in the bovine uterus with adenomyosis. Reprod Biol Endocrinol 13: 110.

Lye SJ, Nicholson BJ, Mascarenhas M, MacKenzie L, Petrocelli $T$ (1993) Increased expression of connexin-43 in the rat myometrium during labor is associated with an increase in the plasma estrogen:progesterone ratio. Endocrinology 132: 2380-2386.

Mayerhofer A, Garfield RE (1995) Immunocytochemical analysis of the expression of gap junction protein connexin 43 in the rat ovary. Mol Reprod Dev 41: 331-338.

Miyamoto Y, Skarzynski DJ, Okuda K (2000) Is tumor necrosis factor $\alpha$ a trigger for the initiation of endometrial prostaglandin $\mathrm{F}_{2 \alpha}$ release at luteolysis in cattle? Biol Reprod 62: 1109-1115.

Moreira L, Carvalho ECQ, Caldas-Bussiere MC (2007) Histopathological aspects of adenomyosis in bovine uteri in different phases of the estrous cycle. Arq Brasi Med Vet Zootec 59: 1097-1102.

Petrocelli T, Lye SJ (1993) Regulation of transcripts encoding the myometrial gap junction protein, connexin-43, by estrogen and progesterone. Endocrinology 133: 284-290.

Regidor PA, Regidor M, Schindler AE, Winterhager E (1997) Aberrant expression pattern of gap junction connexins in endometriotic tissues. Mol Hum Reprod 3: 375-381.

Romek M, Karasinski J (2011) Quantification of connexin43 gap junctions in porcine myometrium by confocal microscopy and stereology. Reprod Domest Anim 46: 29-38.

Saez JC, Berthoud VM, Branes MC, Martinez AD, Beyer EC (2003) Plasma membrane channels formed by connexins: their regulation and functions. Physiol. Rev 83: 1359-1400.

Takahashi K, Nagata H, Kitao M (1989) Clinical usefulness of determination of estradiol levels in the menstrual blood for patients with endometriosis. Nippon Sanka Fujinka Gakkai Zasshi 41: 1849-1850.

Taylor AH, Kalathy V, Habiba M (2014) Estradiol and tamoxifen enhance invasion of endometrial stromal cells in a three-dimensional coculture model of adenomyosis. Fertil Steril 101: 288-293.

van Engelen E, Breeveld-Dwarkasing VN, Everts ME, van der Weyden GC, Taverne MA, Rutten VP (2009) Smooth muscle cells of the bovine cervical stroma may have a secretory, rather than a contractile function during parturition. Reprod Domest Anim 44: 303-311.

Wiesen JF, Midgley AR Jr (1993) Changes in expression of connexin 43 gap junction messenger ribonucleic acid and protein during ovarian follicular growth. Endocrinology 133: 741-746.

Wiesen JF, Midgley AR Jr (1994) Expression of connexin 43 gap junction messenger ribonucleic acid and protein during follicular atresia. Biol Reprod 50: 336-348.

Wrenzycki C, Herrmann D, Carnwath JW, Niemann $\mathrm{H}$ (1996) Expression of the gap junction gene connexin 43 (Cx43) in preimplantation bovine embryos derived in vitro or in vivo. J Reprod Fertil 108: 17-24.

Xu C, You X, Liu W, Sun Q, Ding X, Huang Y, Ni X (2015) Prostaglandin $\mathrm{F}_{2 \alpha}$ regulates the expression of uterine activation proteins via multiple signaling pathways. Reproduction 149: 139-146. 
Yu J, Berga SL, Zou W, Sun HY, Johnston-MacAnanny E, Yalcinkaya T, Sidell N, Bagchi IC, Bagchi MK, Taylor RN (2014) Gap junction blockade induces apoptosis in human endometrial stromal cells. Mol Reprod Dev. 81(7): 666-75.
Zeiler M, Leiser R, Johnson GA, Tinneberg HR, Pfarrer C (2007) Development of an in vitro model for bovine placentation: a comparison of the in vivo and in vitro expression of integrins and components of extracellular matrix in bovine placental cells. Cells Tissues Organs 186: $229-42$. 